\title{
The Employees' Quality of Services based on The Balinese Local Wisdoms at Non Star-rated Hotels in Bali
}

\section{Nyoman Gede Astina, I Komang Gde Bendesa and Agung Suryawan Wiranatha}

Doctorate Program in Tourism, Universitas Udayana, Bali

Corresponding author: secretary@stpbi.ac.id

\section{ARTICLE INFO}

Received

5 December 2016

Accepted

28 March 2017

Available online

31 March 2017

\begin{abstract}
Indonesia is classified as a country that is still promoting traditional culture in seeing service as a profession and business, including in Bali as part of Indonesian territory. Based on empirical studies about the cultural-based service quality, as well as the expectations of tourists to interact with the local knowledge has inspired a new idea to conduct a study on the quality of local wisdom-based services at the non-star hotels in Bali. The problems in this research are what factors that could explain the quality of services of employees based on the Balinese local wisdom at the non-star hotels in Bali. The result of the research showed that variables of local wisdom-based quality of service that play the most important roles are jemet (industrious), tresna (loving), asih (affectionate), and bakti (devotion) or the teaching of the Catur Sewaka which is part of the Sad Sewaka. These four factors are the positive characteristics of the Balinese which are applied in everyday life from generation to generation.
\end{abstract}

Keywords: employees' quality of service and the Balinese local wisdom.

\section{Introduction}

\section{Background}

Service is the main product in the tourism business which depicting the full effort to meet the needs and desires of tourists as the main customers in the tourism business. To that end, a company should be able to build relationships with its customers and conduct mutually beneficial cooperation with all parties involved in the relationship. A company that take a more relational strategies will turn its attention to build relationships with its customers rather than just focus on the sales transaction, so that the company can understand the needs and desires of customers in depth. A relationship that has been established with all customers as

http://ojs.unud.ac.id/index.php/eot mutually beneficial partners may lead to a more complex relationship and grow into business networking.

Employees have an extremely important role in the tourism business, especially in building relationships with customers. Marketing activities are focused on developing relationships through a wide range of services to the needs and desires of tourists. The more services that satisfy the needs and desires of tourists the better the service quality, and conversely the quality of services is considered to be dissatisfied when the services cannot meet the needs and desires of tourists.

Providing excellent services in the field of tourism requires an understanding 
of what will be looked for and evaluated by tourists. To achieve these objectives we need a model that can explain the quality of services perceived by the tourists, so the service providers can manage and serve the customers much better.

Service is mostly an intangible product, as well as a subjective process of production and consumption that will be experienced simultaneously. In this case, the frequency of interaction between the customers and the service providers is very high, so that everything that happens in this interaction affects the quality that perceived by the customers. The nature of the services is related to the expressive dimensions, such as politeness, friendliness, honesty, and empathy which is highly dependent on the employees. Thus, the role of employees in service delivery is a crucial factor in determining the quality of services.

Indonesia is classified as a country that is still promoting traditional culture in providing service as a profession and in business services (Testa and Mueller, 2009), including Bali as part of Indonesia that rely on tourism business as a major driver of the regional economy. Compared with other tourism destinations in Indonesia, there are many places that are geographically much more beautiful than Bali, but the superiority of the characteristics of the Balinese as the human resources in the field of tourism can hardly be found anywhere else.

At first the concept of development of tourism in Bali is a cultural tourism that is based on the philosophy of "Tri Hita Karana" which is recognized as one of the values of local wisdom. The philosophy of "Tri Hita Karana" is defined as the three causes of welfare, referring to the harmonious relationship between man and God, man and the natural world, and man with others who are related to one another (Peters and Wardana, 2013). Among the three values in the philosophy of Tri Hita Karana, the relation among human beings is a value that is related to providing service to tourists. The relations among human beings have been taught and evolved from generation to generation through the teachings of Hinduism and the Balinese culture, including Tri Kaya Parisuda, Tatwam Asi, Salunglung Sabayantaka, Paras Paros Sarpanaya, Bhineka Tunggal Ika, and Menyama Braya (Wisnumurti, 2010).

During its development, the characteristics of the Balinese have degraded in the attitudes and behavior, where modernization and globalization have introduced a new value in the traditions of the Balinese (Triguna, 2011). The Balinese have to compete for economic needs so that the Balinese become competitive individuals with very different attitudes and behavior with the characteristics of humble, naive, patient, kind, and honest. Competition affects the Balinese perceptions about the values of local wisdom, like Tri Kaya Parisuda, Tatwam Asi, Salunglung Sabayantaka, Paras Paros Sarpanaya, Bhineka Tunggal Ika, and Menyama Braya that began to change even very rare to find, especially in urban areas (Triguna, 2011). These changes bear the impression that Bali is for tourism and not as originally planned: tourism is for Bali.

Perceptions of the change in the characteristics of the Balinese are also felt by foreign tourists visiting Bali. In addition to a sense of comfort and uniqueness, tourists also find a bad experience in interacting with the Balinese. The dynamics in the quality of the services proposed by the experts was the reason for carrying out this research on the impact of service quality of employees based on the Balinese local wisdom at non-star hotels in Bali. The results of the study are expected to contribute in the development of hotel services in Bali so as 
to create a sustainable tourism business, as well as to increase knowledge and reference for future research.

The problem analyzed in the study was the factors that explain the quality of service of employees that based on the Balinese local wisdom at non-star hotels in Bali? The practical benefits of the research can be used as a reference in the development of human resources in the tourism sector, especially in the hospitality business. The success of tourism in Bali is inseparable from the role of the Balinese, who are able to create a harmonious relationship with tourists. The Balinese people as human resources play an important role in the creation of quality services to tourists. In the academic field, the results of this research will be useful as one of the sources of reference for science, especially the science of human resource management in tourism and tourism marketing management. In addition, the results of this study can also be used as a reference for future research related to the issues of quality of services.

\section{Research Objective}

Reseach was designed to examine factors that explain the quality of service of employees that based on the Balinese local wisdom at non-star hotels in Bali.

\section{Literature Review}

According to Grönroos (1984) and (Gnoth et al. (2009) service has four basic characteristics, namely: (1) intangible, (2) a set of activities, (3) the process of production and consumption carried out simultaneously, and (4) the existence of consumer participation in the production process. According to Kotler and Armstrong (2003: 368), service has characteristics consisting of: (1) intangible, (2) inseparable, (3) changeable, and (4) not long lasting. Avkiran (1999);

http://ojs.unud.ac.id/index.php/eot
Chenet, Dagger, \& O'Sullivan, (2010); Lovelock \& Wirtz, (2011), service is a series of activities that have the following characteristics: (1) intangible, (2) perishable, (3) variability, (4) produced and consumed simultaneously (inseparable), and (5) the customers to actively participate in the production process. It can be defined from the three notions that service has the characteristics of intangible, inseparable, changeable / variability, perishable, and customers to actively participate in the production process, as well as it lacks of ownership (Cronin Jr and Taylor, 1992; Curry and Sinclair, 2002).

One of the local wisdoms that strongly influences the lives of the Balinese people is the Tri Hita Karana, which implies the three causes of welfare, referring to the harmonious relationship between man and God, man and the natural world, and man with others who are related to one another (Peters and Wardana, 2013).

\section{Concepts and Research Hypothesis}

The study will confirm the factors of quality of service of employees that adopted the local wisdom of Bali at the non-star hotels in Bali. In the concept of the study, the attention will be focused on the services performed by the Balinese employees of non-star hotels in Bali to meet the expectations of foreign tourists as the hotel guests (customers). In the fierce competition among destinations, each destination must have a uniqueness that can be an attraction for tourists, especially the foreign tourists. One of the uniqueness is the local wisdom that is preserved from generation to generation. The result of focus group discussions of academics and practitioners identified the superior characteristics of the Balinese: polos (modest), cucud (meticulous), jemet (industrious), tresna (loving), asih (affectionate), and bakti (devotion). These 
six attitudes of the employees in the concept of quality of service that based on the local wisdom are formulated into the concept of Sad Sewaka. Sad means six and Sewaka means services (Astra, et al., 1986: 530).

The local wisdom is believed to be the superiority of the Balinese in serving the foreign tourists hardly found in other tourist destinations in Indonesia. There are many tourist destinations in Indonesia that are geographically superior to Bali, but the characteristics of the Balinese people are believed to be the superior factors that get the attention of foreign tourists.

\section{Methodology}

This study uses a research design of confirmatory factor analysis. The data collected were cross-sectional; the research activities were carried out in a given period. Locations of the research were done at hotels in the Bali Province. The hotels selected as the location of the research are the non-star hotels scattered in the Province of Bali. The populations in this study were foreign tourists stayed in non-star hotels in Bali with the criteria that have been specified above. The populations were mobile, so they could not be quantified in real count.

\section{Results and Discussion}

The study consisted of validity and reliability tests, using SPSS version 21. The results of the focus group discussion formulated the positive characteristics of the Balinese that reflect the quality of service of the Balinese employees namely, polos (modest), cucud (meticulous), jemet (industrious), tresna (loving), asih (affectionate), and bakti (devotion). Those six characteristics were used as the basis to reflect the quality of service of employees that based on the local wisdom of Bali at the non-star hotels in Bali. Based on the results of the factor analysis, it can be confirmed that the four factors that consistently able to explain the variables of the quality of service of employees that based on the local wisdom of Bali, namely jemet (industrious), tresna (loving), asih (affectionate), and bakti (devotion) or better known as the Catur Sewaka. Factors of polos and cucud could not show the reliability of the construct in accordance with the acceptability requirements in the factor analysis. Thus, the factors are those hotel employees who have the qualities of jemet (industrious), tresna (loving), asih (affectionate), and bakti (devotion).

Factor of jemet or industrious is the services of the hotel employees who are willing to work quickly by creativity and confidence. The perception of tourists of the hard-working hotel employees: always cheerful in every interaction with tourists, happy to serve tourists, diligent workers, and enthusiastic that resolve every demand of tourists, and fast enough to work. These characters are needed by tourists so that the factor analysis confirmed that jemet or industrious character as a factor in the quality of service of employees that based on the local wisdom of Bali.

Tresna or love factor is defined as the services of the hotel employees that were respectful of others. Balinese people's behavior in respect for others led to Bali is famous for its hospitality. The qualities of tresna includes: friendly, always smiling brightly as the hallmark of Bali, polite, respect the conditions of the guests, and employees who are not too busy in serving guests. This character is needed by tourists, so the factor analysis confirmed tresna character as a factor in the quality of service of employees based on local wisdom of Bali.

Factor of asih or affectionate is defined as a hotel employee service by affection. Affection is reflected in the behavior of the hotel employees who provide a touch of compassion for all 
beings in the world. Yadnya or sacred ceremony held in people's daily life in Bali is not only addressed to God and man, but the Balinese also perform yadnya or sacrifices for animals and plants. This behavior reflects that the Balinese have qualities of high affection.

Factor of bhakti is an attitude of humble hotel employees accompanied by measures to convince tourists. Perception of tourists of the hotel employee that the employee is bhakti or being humble in serving tourists, showing no doubt in interacting by tourists, employees act decisively in serving tourists, and employees showed caution over action.

The practical implication that can be used by practitioners of hospitality business is the development of human resources of hospitality can be directed to the four factors of quality of service of employees that based on the local wisdom of Bali, namely: jemet, tresna, asih, and bakti that has been proven to meet the expectations of tourists and encourage the intention of tourists to be faithful to the hotels. These factors constitute the character of the Balinese who become employees of non-star hotels in Balinese, so the hotel, can apply it easily in the development of human resources. These characters are not easily found on other employees who are not Balinese, because they do not know such Balinese local wisdom in their daily lives.

The research results provide practical implications for practitioners of non-star hotels in competing in the global era. Having the competition head to head with five-star hotels that obiously have a better technological and financial supports will not lead to satisfactory results. Nonstar hotels in Bali can apply blue ocean strategy by relying on the role of employees in providing unique services based on the local wisdom of Bali. Services that apply the principles of the
Balinese characteristics could lead to a positive response of foreign tourists to interact with the hotel employees, so they prefer the non-star hotels rather than fivestar hotels, they feel their mood better when they stay in non-star hotels, and they love non-star hotel and their services. The interactions of the hotel employees who give special attention to foreign tourists, excellent hotel employees' attitudes and behaviors, efficient services of employees, as well as proiding services beyond the expectations of foreign tourists are very important in realizing better emotion, mood, and the positive attitude of foreign tourists. Consequently, these attitudes may generate the customers'satisfaction on the services of non-star hotels in Bali.

\section{Contributions of employees in} providing services may include a presentable appearance of the employees, a willingness to apologize for any mistakes made, courtesy of employees, special attention given to guests, and providing services that satisfy the needs of the guests, and knowledgeable so that they can make the guests feel comfortable, the ability to provide information related to the hotel, knowledge in hotel equipments, and knowledge about the prices on hotel services. In this case, the satisfaction of hotel guests on the services should be more emphasis on the emotional aspect in the evaluation of perceived services. The foreign tourists believe that the services of hotel employees of non-star hotels in Bali may lead to a positive feeling.

The uniqueness of this study is the satisfaction of foreign tourists on the services of non-star hotel employees that based on the Balinese local wisdom which significantly effect on the behavioral intentions. This research has not been done before and these findings can be used as a reference by practicing hospitality and other service companies to create customers' satisfaction for sustainable businesses. Hotels must understand what 
the needs of their guests, even at a higher level, they must understand what the guests want, and how to meet those needs and wants in order to create satisfaction and positive behavioral intentions of the guests.

\section{Conclusions and Recommendation}

\section{Quality of service is not always} based on financial capital and technological factors commonly made by hotels. This study found that the Balinese local wisdom can be the determining factor in creating a good quality of service in the non-star hotels in Bali. Characteristics of jemet (industrious), tresna (loving), asih (affectionate), and bakti (devotion) or Catur Sewaka found in the attitude and behavior of the Balinese hotel employees has very well perceived by tourists in meeting their needs and wants as hotel guests. This will lead to customers' satisfaction that they can be loyal customers or guests. These findings should be used by practitioners of the hospitality business, particularly the small non-star hotels to serve tourists who stay in their hotels so that it can maintain the existing guests to be repeated guests.

Satisfaction has been found to mediate the relationship between the quality of serices that based on the Balinese local wisdom and the behavioral intentions of the tourists at the small nonstar hotels in Bali. Satisfaction of tourists is concerned with the expectations of tourists, so that the hospitality practitioners should pay more attention on the expectation or interest of tourists in managing the local wisdom of Bali on the hotel services. Not all local wisdom of Bali that are considered favorable by the Balinese may satisfy the the tourists to be loyal to the non-star hotels in Bali. Thus, the hospitality practitioners should consider the needs and wants of the tourists in deciding policy to utilize local wisdom of Bali on their services.
It can be recommended to academics that the research has found the Balinese local wisdom can be a dimension of service quality and contribute to the development of knowledge, particularly in providing services. These findings should be used by academics in carrying out research in the field of services by reference to the factors of service quality that based on the local wisdom of Bali. Thus, the future research may add insight into the quality of service that has so far been more emphasized on the servqual models. Other suggestion is that the model built in this study is not limited to the quality of service of employees at small non-star hotels in Bali. In the future research, it should be studied the quality of service that based on the local wisdom of Bali which is applied to other areas of the tourism services, such as star hotels, restaurants, spas, bars, travel agencies, and others that provide services. In the broader scope of this research, it can be suggested for service business outside the tourism sector, such as banks, hospitals, transportation, and education. The more widespread the adoption of services which based on the local wisdom of Bali, the greater the Balinese cultural maintenance.

\section{References}

Avkiran, N. K. (1999) 'Quality customer service demands human contact', International Journal of Bank Marketing. MCB UP Ltd, 17(2), pp. 61-74.

Chenet, P., Dagger, T. S. and O'Sullivan, D. (2010) 'Service quality, trust, commitment and service differentiation in business relationships', Journal of Services Marketing. Emerald Group Publishing Limited, 24(5), pp. 336-346. 
Cronin Jr, J. J. and Taylor, S. A. (1992) 'Measuring service quality: a reexamination and extension', The journal of marketing. JSTOR, pp. 55-68.

Curry, A. and Sinclair, E. (2002) 'Assessing the quality of physiotherapy services using SERVQUAL', International Journal of Health Care Quality Assurance. MCB UP Ltd, 15(5), pp. 197-205.

Gnoth, J., Andreu, L., Kozak, M., Enrique Bigné, J., Sánchez, I. and Andreu, L. (2009) 'The role of variety seeking in short and long run revisit intentions in holiday destinations', International Journal of Culture, Tourism and Hospitality Research. Emerald Group Publishing Limited, 3(2), pp. 103-115.

Grönroos, C. (1984) 'A service quality model and its marketing implications', European Journal of marketing. MCB UP Ltd, 18(4), pp. 36-44.

Kotler, P. and Armstrong, G. (2003) Principles of Marketing.ed.9. 2001. Prentice Hall. Inc.

Lovelock, C. H. and Wirtz, J. (2011) Service Marketing. People, Technology, Strategy 6e. United State of America: Pearson Prentice Hall.

Peters, J. H. and Wardana, W. (2013) Tri Hita Karana. The Spirit of Bali. Jakarta: PT. Gramedia.

Triguna, I. B. G. Y. (2011) Mengapa Bali Unik? Jakarta: Pustaka Jurnal Keluarga.
Wisnumurti, O. A. A. G. (2010) Mengelola Nilai Kearifan Lokal dalam Mewujudkan Kerukunan Umat Beragama. Suatu Tinjauan Empiri-Sosiologis. Yayasan Kesejahteraan Korpri Provinsi Bali. Medion Technocentra. 